\title{
Wastewater Treatment in the Urban Environment
}

\author{
Ranka Junge-Berberovic and Andreas Graber \\ University of Applied Sciences Waedenswil \\ Dept. Natural Resource Sciences \\ Gruental 40 \\ 8820 Waedenswil, Switzerland
}

Keywords: constructed wetlands, urban development, closed loop, water and nutrient cycle, climate regulation

\begin{abstract}
Constructed wetlands are a valid option for wastewater treatment even in urban areas. In the city, they can be implemented in roof tops, abandoned industrial areas, vertical surfaces of buildings, backyards, porches and public parks. In the suburbs, greywater can be treated in private gardens and reused for irrigation. The performance and control restraints often found disappointing in nature-based systems have been overcome in the past two decades: current systems achieve effluent qualities similar to conventional sewage treatment plants. With area requirements expected to come down to $2.0 \mathrm{~m}^{2}$ per p.e. they would need only two or three times more space. To the core task of treating wastewater they add valuable ecosystem services like micro-climate regulation, rainwater retention, production of renewable energy and/or food, air filtering, noise reduction and recreational values as biotopes with flora and fauna. They represent a new philosophy of dealing with wastes: recycling of nutrients from a valuable resource instead of mere disposal. The new concepts of closing loops call for a more integrated approach represented by the ecological engineer. With its expertise in landscape design and plant usage, horticulture is a key science to promote ecological engineering.
\end{abstract}

\section{INTRODUCTION}

Concern with management of the world's freshwater resources is growing, and more than a billion people lack clean drinking water. At present, in developing countries there is little or no treatment of water and health risks are high due to poor hygiene. In developed countries rain and wastewater disappear under the surface, treated water is led into rivers and quickly leaves the catchment area. Treatment is effective and sanitation achieved, but the system demands energy and incurs high costs.

These situations result from two different philosophies in water supply. The "hard path" relies on a centralized infrastructure to capture, treat and deliver water supplies, whereas the "soft path" seeks to improve the overall productivity of water use and deliver water services matched to the needs of end users, rather than seeking new sources of supply (Gleick 2002).

One solution is an alternative sanitation concept called "ecological sanitation", or "ecosan" for short. The key objective of this approach is a new philosophy of dealing with what in the past has been regarded as waste and wastewater. Ideally, ecosan systems enable the complete recovery of all nutrients from human faeces, urine and greywater to the benefit of agriculture, thus helping to restore soil fertility, to assure food security for future generations, and to minimize water pollution while ensuring that water is used economically and reused for such purposes as irrigation, groundwater recharge or even direct reuse (Werner et al. 2000).

One ecosan concept is the household-centered environmental sanitation approach where wastewater is regarded as a resource and treated and recycled as close to its source as possible. The "closed loop" approach should replace the "linear approach". These solutions are essentially decentralised: The domain in which environmental sanitation problems are resolved should be kept to the minimum practicable size and wastes diluted as little as possible (Schertenleib 2001). 
The arguments for decentralisation of the wastewater management in urban areas are gaining weight as time goes by. The main point is the very expensive piping systems which cause about $75 \%$ of the treatment costs (Bahlo and Wach 1992). Piping also has to be replaced at regular intervals (roughly every 150 years, Dakers 2000). Conventional treatment produces large amounts of sludge, $190 \mathrm{~g}$ solid and diluted wastes per person per day yield $50 \mathrm{~g}$ primary sludge and $93 \mathrm{~g}$ secondary sludge (Wissing 1995). In addition, neither nutrients $(\mathrm{N}, \mathrm{P}, \mathrm{K})$ nor the treated water are recycled, re-used or retained, but leave the city. In contrast, Steen (1998) states that recycling of non-renewable nutrients is increasingly urgent.

While there is a broad consensus that "soft paths" and "ecosan" are applicable strategies for developing countries, their application in developed countries is hindered by existing centralised infrastructures and by legislation, especially in urban environments. There are some arguments for not decentralising wastewater management in the urban areas. In most countries, legislation enforces sewer connection to ensure sanitation of wastes. Once the centralised infrastructure is established, there is economic pressure to make use of the systems for as long as possible. Decentralised systems require more control and pose an increased potential for hazards in terms of hygiene or toxic substances. Especially in megacities, space limitation demands treatment systems with maximum performance per area.

There are now more than 500 constructed wetlands in Europe and 600 in North America (Unsoeld 1999). Nevertheless, compared to research on sewage treatment plants (STPs), research on constructed wetlands is still in its infancy (VSA 1995; Wissing 1995; Lange and Otterpohl 1997). Constructed wetlands are engineered systems designed to utilize the natural processes involving wetland vegetation, soils, and their associated microbial assemblages to assist in treating wastewater (Bastian 1993). Wastewater is pumped through a planted soil, gravel or sand matrix either in horizontal or vertical flow. The systems differ in construction type (aerobic, anaerobic) and can be manipulated by changing the plant species, the retention time and the nutrient concentration of the wastewater (Bahlo and Wach 1992). They may be classified according to the life form of the dominating macrophyte as either free-floating macrophyte-based, submerged macrophyte-based or rooted emergent macrophyte-based (Brix 1993). The latter can also be termed planted soil filters (Wyss and Züst 2000). Processes responsible for nutrient elimination are various: nitrogen-compounds are transformed and eliminated by nitrification and denitrification, whereas phosphates are accumulated. As long-term investigations do not exist, it is not known when the accumulation capacity is satiated. Vymazal et al. (1998) found that phosphate retention improved over the years. The question is whether the same accumulation will be found for endocrine disruptors and other xenobiotica.

The disadvantage of many projects in extensive wastewater treatment is that the functioning of the plants is not properly monitored. With the use of traditional engineering methods of analysis, this situation can be improved (Larsen 1996).

By 2025, two-thirds of the world's people will live in urban areas (Wilson 1996). This will cause a number of problems: providing food and drinking water, eliminating pollution as well as climate regulation of dry and hot cities. Many characteristics of constructed wetlands could contribute to the solution of some of these problems, provided they can be included in the urban environment. The present paper will try to answer the question: Are constructed wetlands a valid option for wastewater treatment in urban areas?

\section{RESULTS}

The wide range of systems for constructed wetlands offers solutions for many situations: horizontal and vertical flow, different substrates and plant species allow for enough plasticity to adapt to different needs. And they do their job very well: for biodegradable parameters the purification efficiency is more than $98 \%$ (Table 1).

However, the main factor limiting their application is often space. As most 
systems serve as a pilot project, engineers tend to secure good operation by overdimensioning. The area requirements currently in use are $5 \mathrm{~m}^{2}$ per population equivalent (p.e.) but often even more area is used. Conventional sewage treatment plants (STPs) perform far better for $0.6 \mathrm{~m}^{2}$ per p.e. are enough for BOD reduction (Table 1). A complete nitrogen purification (NB elimination via denitrification, not usage) requires 1.3 $\mathrm{m}^{2}$ per p.e.. Mori (2001) states that constructed wetlands can be further improved and operated safely at $2.0 \mathrm{~m}^{2}$ per p.e.. If so, they would perform within 30 to $60 \%$ of STPs and thus become very attractive alternatives for blackwater treatment. Staudenmann and Junge (2000) used floating macrophytes to recycle nutrients from biogas-effluent with good results: water hyacinths removed up to $0.9 \mathrm{~g} \mathrm{~N} \mathrm{~m}^{-2} \mathrm{~d}^{-1}$ and $0.2 \mathrm{~g} \mathrm{P} \mathrm{m}^{-2} \mathrm{~d}^{-1}$.

As added benefits, constructed wetlands in the city offer ecosystem services like micro-climate regulation (cooling by enabling natural climate regulation via transpiration and thus decrease of energy use for climatization, reduced wind speed), rainwater retention, habitat for fauna, production of renewable energy and/or food, air filtering (vegetation reduces air pollution), noise reduction and recreational values.

At present, only a few isolated projects in urban areas are seeking to promote the new ideas of the "soft path". Most constructed wetlands in Europe are situated in rural areas (Vymazal et al. 1998). One of the first projects in western Europe with an integrated water management concept was "Block 6, Berlin Kreuzberg". It encompasses water saving devices and strategies, wastewater treatment in constructed wetlands and recycling of (rain)water. The rainwater retention pool and the planted soil filter are integrated in the free spaces of the settlement (Hahn et al. 1988). Some of these concepts were also realised in "Flintenbreite" (Otterpohl 2000), an ecocity constructed for the German Expo2000 in Hannover.

One of the most ambitious uses of wetlands in a city was proposed by the Swiss architects Herzog and de Meuron for Barcelona but was never realised (Mack 1996). Herzog and de Meuron developed a vision of wastewater treatment as an integral part of the urban landscape: "The new plant should form the visible part of a water cycle, and fulfill functional and design requirements." The plant should be a combination of mechanical-chemical treatment and extensive constructed wetland between the city and the sea. The total system would have comprised 16 ha along the Mediterranean and 19 ha scattered throughout the city, consisting of single 1 ha squares of $105 \mathrm{~m}$ side. At present, wastewater of 3 million p.e. is treated in the conventional STP Bésos and discharged into the sea. The nature-based system could serve as secondary treatment of part of this effluent, yielding irrigation water for parks and gardens in the city. Junge and Graber (2001) calculated the possible impacts of such a huge system: it could treat the raw wastewater of up to 60,000 people or, used as secondary treatment, 1 ha soil filter would "produce" 0.4 million litres of water per year, including precipitation and evapotranspiration.

\section{DISCUSSION}

Brenneisen (2003) investigated the potential for green roofs in Basel City, and found that $10 \%$ of the area was covered with usable flat roofs. Basically, where green roofs are applicable, constructed wetlands could also be implemented, making them a special kind of "green roof". In order to evaluate this potential, it makes sense to distinguish between city and suburb.

The city proves to be the difficult place to start with: Space is extremely limited and expensive (e.g. Berlin City 10,000 $\$ / \mathrm{m}^{2}$ ), it has a dense population and high pace of life, and water flows are fast and hidden. Nevertheless, there is potential for decentralisation, but it is limited and barely imaginable without changes in legislation. Turner (1995) states that many cities contain vast tracts of potentially productive derelict land; 40,000 ha of such land were estimated for London and over 70,000 ha for New York.

Some possible areas include roof tops, abandoned industrial areas, vertical surfaces of buildings, backyards, porches and public parks. Roofs could be covered with 
planted soil filters for rain retention and water purification. Where waste heat is available, flat roofs could be equipped with greenhouse aquaponics. To avoid hygiene problems, only grey water should be used, black water could still be handled in conventional sewage treatment plants or be separated and composted. As shown by Staudenmann and Junge (2000), shallow water basins could be constructed for nutrient recovery from specific industrial wastewaters. Other possibilites exist to use and treat water locally. Industrial surfaces and recreation areas can act as space for rainwater retention, while the self purification capacity of planted soil filter strips along streams or even constructed city streams can be utilized.

The suburbs are characterized by lower land prices, population is less dense and the pace of life slower (sleeping quarters), building units are smaller, but nevertheless water flows are still fast and hidden. Private gardens offer good potential for decentralisation, but lobbying is necessary and costs are decisive. One has to consider that STPs only treat water while constructed wetlands also provide other services. If this is taken into account, area optimisation should not be the only decisive parameter.

If constructed wetlands are to be applied in urban areas, legislation should allow for decentralised solutions in urban areas or even support them, and the proposed concepts should be impartial regarding the technology, aiming at the best adapted solution without any preconceptions. Moreover, different technologies from extensive to intensive should be combined in order to achieve multiple positive effects.

There has to be further development of systems and improved process control. Research has to gain more importance and funding, as further research might improve the treatment efficiency of constructed wetlands in order to make them more competitive with conventional STP technology (Table 1). Research is also needed to achieve optimization of the effluent according to its planned further use (irrigation) and/or release into the environment, to increase the efficiency of treatment and thus reduce the area of wetland required, and to investigate the fate of single pollutants, like hormones and heavy metals. New design solutions should emerge from collaboration between architects and ecological engineers.

Why should horticulturists care about wastewater treatment? For decades, this was clearly the task of civil engineers. The new concepts of closing loops call for a more integrated approach represented by the ecological engineer. With its expertise in landscape design and plant usage, horticulture is a key science to promote ecological engineering. The ongoing research at the University of Applied Sciences Waedenswil focuses on wastewater-fed aquaculture as well as other types of constructed wetlands and integrated production systems. The emphasis is upon optimization of modular systems, maximization of the performance of plants and elaboration of user guidelines. The Department of Horticulture was involved in several ecological engineering projects : recycling of nutrients and water in the wastewater-fed aquaculture Otelfingen (Staudenmann and Junge 2003), ecological improvement of greenhouse cultivation by integration of aquaculture with tilapia (Todt 2003), waste heat utilization in an integrated fish and vegetable production system called aquaponics (Graber 2003), development of methods for sustainable wastewater management in Bosnia-Herzegovina, and the phytoremediation of heavy metals (for a complete list of projects see www.hortikultur.ch).

Thus the Department of Horticulture provides innovation, development and research for implementation of constructed wetlands in urban areas and new solutions for indoor and outdoor space through a combination of design, ecology and economy.

\section{Literature Cited}

Bahlo, K. and Wach, G. 1992. Naturnahe Abwasserreinigung. Ökobuch Verlag, Staufen bei Freiburg.

Bastian, R.K. (ed.).1993. Constructed Wetlands for wastewater Treatment and Wildlife Habitat. 17 Case Studies. United States Environmental Protection Agency. EPA 832R-93-005, Municipal Technology Branch, Washington, DC. 
Brenneisen, S. 2003. Ökologisches Ausgleichspotenzial von extensiven Dachbegrünungen. Dissertation University Basel, 192 p.

Brix, H. 1993. Wastewater treatment in constructed wetlands: system design, removal processes, and treatment performance. In : Moshiri, G.A. (ed.), Constructed Wetlands for Water Quality Improvement, pp. 9-22. CRC Press, Boca Raton, Florida.

Dakers, A. 2000. Ecological Engineering and Urban Design: Engineering our ecological fit. In: Stewart, G.H. \& Ignatieva, M. E. (eds) Urban Biodiversity and ecology as a basis for holistic planning and design. Proceedings of a workshop held on October 2829, 2000. Lincoln University, Wickliffe Press, Christchurch. ICNC Publication No.1. 111pp. ISBN 0-86476-136-8.

Gleick, P.H. 2002. Soft water paths. Nature, 408:373.

Graber, A. 2003. Vom Tropenhaus zum Agrarpark, Anwendungen von Polykulturen in der Schweiz. Conference on Polycultures, Waedenswil April 25th. http://www.hortikultur.ch/pub/files/160.pdf

Hagendorf, U. \& Hahn, J. 1994. Untersuchungen zur umwelt- und seuchenhygienischen Bewertung naturnaher Abwasserbehandlungssysteme. Texte Umweltbundesamt 60/94. Berlin.

Hahn, E., P. Thomas, J. Zeisel 1988. Dezentrale Wasseraufbereitung - eine Pflanzenkläranlage in der Diskussion. In: Grohe, T., F. Ranft $(\mathrm{Hg})$ Ökologie und Stadterneuerung - Anforderungen, Handlungsmöglichkeiten und praktische Erfahrungen. Köln, Kohlhammer, p. 135-153.

Junge, R. \& A. Graber 2001. Naturnah klären. Baubiologie 3:27-30.

Lange, J., \& R. Otterpohl 1997. Abwasser - Handbuch zu einer zukunftsfähigen Wasserwirtschaft. Mallbeton GmbH, Pfohren, Germany.

Larsen, T. 1996. Basics of Systems Analysis for Wastewater Treatment. In: J. Staudenmann, A. Schoenborn, and C. Etnier (Eds.), Recycling the Resource. Proceedings of the 2nd Int. Conf. on Ecological Engineering for Wastewater Treatment. Transtech Publications, CH-Uetikon. pp. 73 - 82.

Mack, G. 1996. Herzog \& de Meuron 1989-1991. Das Gesamtwerk, Band 2. Birkhäuser Verlag.

Mori, K. 2001. www.moritec.ch

Otterpohl, R. 2000. http://www.otterwasser.de/german/konzepte/flintg.htm and www.flintenbreite.de

Siegl, A., Bruch, I., Mühl, M. 1997. Gestaltung von Abwasserbehandlungsanlagen im ländlichen Raum. Abschlussbericht Projekt A 5.29 Länderarbeitsgemeinschaft Wasser (LAWA) 1996/97. $155 \mathrm{~S}$.

Schertenleib, R. 2001. The Bellagio Principles and a household centered approach in environmental sanitation. In: Ecosan - closing the loop in wastewater management and sanitation. Proceedings of the International Symposium, Deutsche Gesellschaft für Technische Zusammenarbeit (GTZ). October 30-31 2000, Bonn, Germany. 327 pp. www.gtz.de.

Staudenmann J., and Junge-Berberovic, R. 2000. Treating biogas plant effluent through aquaculture: first results and experiences from the pilot plant Otelfingen (Switzerland) In: Jana, B.B., Banerjee, R.D., Guterstam. B., and Heeb J. (eds): Waste recycling and resource management in the developing world. University of Kalyani, India and Int. Ecol. Eng. Soc., Switzerland. 51-57 pp.

Staudenmann, J., Junge-Berberovic, R. 2003. Recycling Nutrients from Industrial Wastewater by Aquaculture Systems in Temperate Climates (Switzerland). Journal of Applied Aquaculture, Vol. 13, No.1/2, pp. 67-101.

Steen, I. 1998. Phosphorus availability in the 21st century: Management of a nonrenewable resource. Phosphate \& Potassium 217.

Todt, D. 2003. Erobern Tropenfrüchte unsere Gewächshäuser? Der Gartenbau 12/2003, p $16-17$

Turner, T. 1995. The Conserver Society - Alternatives for Sustainability. Zed Books, London, Ch. 3 Food and Agriculture . 
Unsoeld, K. 1999. Constructed wetlands for wastewater treatment. www.olywa.net

VSA (Verband Schweizer Abwasser- und Gewaesserschutzfachleute).1995. Die Klaerschlammsituation in der Schweiz. Verbandsbericht Nr. 495. Zürich, Switzerland

Vymazal J., Brix H., Cooper P.F., Green M.B., Haberl R.(eds) 1998. Constructed wetlands for wastewater treatment in Europe. Backhuys Publishers, Leiden, 366pp..

Werner, C., Schlick, J., Witte, G., Hildebrandt, A. 2000. Ecosan - closing the loop in wastewater management and sanitation. Proceedings of the International Symposium, Deutsche Gesellschaft für Technische Zusammenarbeit (GTZ), October 30-31, Bonn, Germany. 327 pp. www.gtz.de.

Wilson, E. 1996. Urbanization and Agriculture to the Year 2020. 2020 News \& views, April 1996. http://www.ifpri.org/2020/newslet/nv_0496.htm

Wissing, F. 1995: Wasserreinigung mit Pflanzen. Ulmer Verlag, Stuttgart. 207 p

Wyss, P. and Züst, B. 2000. Sustainable wastewater treatment with soil filters. Intermediate Technology Publications 103-105 Southampton Row, London WC1B 4HH, UK, orders@itpubs.org.uk. 


\section{$\underline{\text { Table }}$}

Table 1. Comparison of wastewater treatment systems

\begin{tabular}{|c|c|c|c|c|c|c|c|c|c|c|c|c|c|}
\hline \multirow[b]{2}{*}{$\begin{array}{l}\text { Type of constructed } \\
\text { wetland }(\mathrm{CW})\end{array}$} & \multirow[t]{2}{*}{ Author } & \multicolumn{4}{|c|}{$\begin{array}{c}\text { Elimination rates } \\
{[\%]} \\
\end{array}$} & \multicolumn{4}{|c|}{$\begin{array}{c}\text { Elimination rates } \\
{\left[\mathrm{g} \mathrm{m}^{-2} \mathrm{~d}^{-1}\right]} \\
\end{array}$} & \multicolumn{4}{|c|}{$\begin{array}{c}\text { Area requirements } \\
{\left[\mathrm{m}^{2} \mathbf{P E}^{-1}\right]} \\
\end{array}$} \\
\hline & & COD & $\mathrm{BOD}_{5}$ & Ntot & Ptot & COD & $\mathrm{BOD}_{5}$ & Ntot & Ptot & COD & BOD $_{5}$ & Ntot & Ptot \\
\hline $\begin{array}{l}\text { Root zone system in the } \\
80 \text { s }\end{array}$ & $\begin{array}{c}\text { Hagendorf \& } \\
\text { Hahn, } 1994\end{array}$ & 44 & 54 & 34 & 19 & & 3.1 & & & & 13.1 & & \\
\hline $\begin{array}{l}\text { older planted soil } \\
\text { filters, mostly } \\
\text { horizontal flow }\end{array}$ & $\begin{array}{l}\text { Hagendorf \& } \\
\text { Hahn, } 1994\end{array}$ & 83 & 91 & 56 & 72 & 6.9 & 2.9 & 1.2 & 0.3 & 11.5 & 13.6 & 8.7 & 8.8 \\
\hline $\begin{array}{l}\text { new planted soil filters, } \\
\text { mostly vertical flow }\end{array}$ & Siegl et al., 1997 & 93 & 97 & 63 & 83 & 19.6 & 6.6 & 1.9 & 0.6 & 4.1 & 6.1 & 5.3 & 4.2 \\
\hline $\begin{array}{l}\text { Wastewater-fed } \\
\text { aquaculture Otelfingen }\end{array}$ & $\begin{array}{l}\text { Staudenmann and } \\
\text { Junge, } 2003\end{array}$ & $>90$ & $>98$ & $>99$ & $>99$ & 3.8 & & 0.4 & 0.1 & 20.9 & & 23.8 & 28.8 \\
\hline $\begin{array}{l}\text { Macrophytes } \\
\text { (maxima achieved in } \\
\text { Otelfingen) }\end{array}$ & $\begin{array}{l}\text { Staudenmann and } \\
\text { Junge, } 2003\end{array}$ & & & & & & & 0.9 & 0.2 & & & 11.5 & 15.1 \\
\hline $\begin{array}{l}\text { values that can be } \\
\text { attained with present } \\
\text { technology of CW } \\
\left(2 \mathrm{~m}^{2} / \text { p.e. }\right)\end{array}$ & & & & & & 40 & 20 & 5.5 & 1.2 & 2.0 & 2.0 & 2.0 & 2.0 \\
\hline $\begin{array}{l}\text { STP Rietliau- } \\
\text { Waedenswil (2000) }\end{array}$ & this study & 91 & 98 & 39 & 96 & 143 & 66 & 8.0 & 2.2 & 0.6 & 0.6 & 1.3 & 1.1 \\
\hline $\begin{array}{l}\text { Comparison of } \\
\text { performance } \\
\text { CW / STP [\%] }\end{array}$ & & & & & & 28 & 30 & 63 & 53 & 28 & 30 & 63 & 53 \\
\hline
\end{tabular}

